\title{
Pengaruh Penggunaan Informasi Akuntansi Manajemen dan Kepribadian Wirausaha Terhadap Pengembangan Kewirausahaan Bidang Ekonomi Kreatif di Kota Jambi
}

\author{
Netty Herawaty dan Reni Yustien \\ Dosen Fakultas Ekonomi dan Bisnis Universitas Jambi \\ Email: netherawaty@gmail.com; reni_yustien@ymail.com
}

\begin{abstract}
ABSTRAK
Tujuan penelitian ini adalah untuk menganalisis apakah ada pengaruh penggunaan informasi akuntansi manajemen, kepribadian wirausaha terhadap pengembangan kewirausahaan bidang ekonomi kreatif di Kota Jambi, untuk menganalisis apakah ada pengaruh penggunaan informasi akuntansi manajemen terhadap pengembangan kewirausahaan bidang ekonomi kreatif di Kota Jambi dan untuk menganalisis apakah ada pengaruh kepribadian wirausaha terhadap pengembangan kewirausahaan bidang ekonomi kreatif di Kota Jambi. Penelitian ini menggunakan alat analisis regresi berganda dengan terlebih dahulu mengkonversikan skala ordinal ke skala interval melalui metode interval berurutan (Method of successive interval). Asumsi klasik yang digunakan dalam penelitian ini adalah uji normalitas bertujuan untuk menguji apakah dalam model regresi variabel terikat dan variabel bebas keduanya mempunyai distribusi normal atau tidak. Model regresi yang baik adalah memiliki distribusi data normal atau mendekati normal. Asumsi multikolinearitas yaitu situasi adanya korelasi variabelvariabel bebas antara yang satu dengan yang lainnya. Menurut Gujarati (2003:157), multikolinearitas berarti adanya hubungan linear yang sempurna atau pasti, diantara beberapa atau semua variabel yang menjelaskan dari model regresi. Asumsi Heteroskedastisitas yaitu data cross section mengandung situasi heterokedastis karena data tersebut menghimpun data yang mewakili berbagai ukuran. Penelitian ini menggunakan data primer Data primer diperoleh langsung dengan menyebar kuesioner kepada responden. Kuesioner atau angket merupakan alat pengumpulan data yang berupa serangkaian daftar pertanyaan untuk dijawab responden (hariwijaya dan Triton;2008). Responden pada penelitian ini yaitu pemilik dan perajin batik di Kota Jambi. Hasil penelitian ini adalah variabel penggunaan sistem informasi manajemen $\left(\mathrm{X}_{1}\right)$, kepribadian wirausaha $\left(\mathrm{X}_{2}\right)$, secara simultan dan parsial tidak memiliki pengaruh terhadap pengembangan kewirausahaan (Y).
\end{abstract}

\section{Kata kunci: Sistem Informasi Manajemen, Kepribadian Wirausaha, Pengembangan Kewirausahaan}

\section{PENDAHULUAN}

Usaha Kecil Menengah (UKM) dan Usaha Mikro Kecil dan Menengah (UMKM) merupakan salah satu tiang atau penyangga perekonomian di Indonesia. Hal ini dapat terlihat dari bukti nyata bahwa sebagian besar UKM/UMKM di Indonesia tidak menghadapi krisis di tengah-tengah krisis global pada tahun 2008 lalu. Perkembangan jumlah UKM/UMKM dari tahun ke tahun semakin bertambah walaupun dalam hal persentase masih kalah dibandingkan Singapura, Malaysia dan Thailand. Meski begitu dibandingkan dengan negara tetangga lainnya, Indonesia merupakan negara yang memiliki UKM/UMKM terbesar sejak tahun 2014. 
Menurut data BPS 2014, jumlah UMKM di Indonesia memiliki 57,89 juta unit atau 99,99 persen dari total jumlah pelaku usaha nasional.

Berdasarkan Data Kementerian Koperasi dan UKM, jumlah wirausahawan di Indonesia pun melonjak tajam dari 0,24 persen menjadi 1,56 persen dari jumlah penduduk. Meski begitu jumlah tersebut masih jauh dari target wirausaha Indonesia yang harusnya idealnya minimum 2 persen dari jumlah penduduk. UKM/UMKM di Indonesia, sering dikaitkan dengan masalah-masalah ekonomi dan sosial dalam negeri seperti tingginya tingkat kemiskinan, besarnya jumlah pengangguran, ketimpangan distribusi pendapatan, proses pembangunan yang tidak merata antara daerah perkotaan dan perdesaan, serta masalah urbanisasi. Menurut World Bank, Indonesia sendiri sumber penghidupan sangat bergantung pada sektor UKM. Kebanyakan usaha kecil ini terkonsentrasi pada sektor perdagangan, pangan, olahan pangan, tekstil dan garmen, kayu dan produk kayu, serta produksi mineral non-logam. Secara keseluruhan, sektor UKM diperkirakan menyumbang sekitar lebih dari 50\% PDB (kebanyakan berada di sektor perdagangan dan pertanian) dan sekitar $10 \%$ dari ekspor. (Nely Merlina:2014)

Ekonomi kreatif menurut Departemen Perdagangan RI (2008) yaitu upaya pembangunan ekonomi secara berkelanjutan melalui kreatifitas dengan iklim perekonomian berdaya saing dan memiliki cadangan sumber daya yang terbarukan. Ekonomi kreatif sebagai industri yang berasal dari pemanfaatan kreatifitas, keterampilan serta bakat individu demi menciptakan kesejahteraan dengan menghasilkan dan mengeksploitasi daya kreasi dan cipta individu tersebut. Pemberdayaan usaha mikro kecil dan menengah (UMKM) merupakan langkah yang strategis dalam meningkatkan dan memperkuat dasar kehidupan perekonomian dari sebagian besar rakyat Indonesia, khususnya melalui penyediaan lapangan kerja dan mengurangi kesenjangan dan tingkat kemiskinan, namun demikian disadari pula bahwa pengembangan usaha kecil menghadapi beberapa kendala seperti tingkat kemampuan, keterampilan, keahlian, manajemen SDM, kewirausahaan, pemasaran dan keuangan. Lemahnya kemampuan manajerial dan SDM mengakibatkan pengusaha kecil tidak mampu menjalankan usahanya dengan baik. (Rosmiati:2012)

Penyajian informasi akuntansi agar tidak menyesatkan pemakainya maka penyajian informasi harus berkualitas. Informasi merupakan suatu komponen yang sangat penting dalam suatu organisasi atau boleh dikatakan bahwa tanpa informasi maka tidak akan ada perusahaan. Informasi akan menjadi perekat antara orang-orang yang ada dalam perusahaan. Informasi memiliki peranan yang sangat penting karena itu harus dikelola dengan baik guna menghasilkan informasi yang berkualitas dan dapat digunakan untuk pengambilan keputusan. Informasi yang berkualitas harus memenuhi syarat yaitu relevan, tepat waktu, akurat dan lengkap. (Azhar;2002). Informasi akuntansi adalah satu hal penting yang dibutuhkan dalam menunjang keberhasilan sebuah kelompok usaha mandiri. Adanya informasi akuntansi dapat membantu dalam menyelenggarakan kegiatan kelompok usaha mandiri. Informasi ini digunakan dalam pengambilan keputusan internal organisasi dan pengambilan keputusan eksternal. Kepribadian wirausaha adalah seluruh konsep, pengetahuan yang abstrak untuk memperoleh sumber daya yang bernilai rendah, secara eksplisit, dan bagaimana menyebarkan sumber daya. Menurut Kirzner dan Schumpeter (2004) dalam Rambat Lupiyoadi (2006) menggambarkan peran seseorang wirausaha seperti keputusan untuk mengarahkan input ke dalam proses tertentu dari pada proses lainnya. Kewirausahaan ada suatu disiplin ilmu yang 
mempelajari tentang nilai, kemampuan dan perilaku seseorang dalam menghadapi tantangan hidup dan cara memperoleh peluang dengan berbagai risiko yang mungkin dihadapinya.

Batik Jambi sudah mulai dikenal di nusantara, namun untuk memenuhi permintaan pasar, batik Jambi ada yang diproduksi di Jawa. Hal ini memperlihatkan bahwa Propinsi Jambi belum mampu memenuhi permintaan pasar. Industri batik khususnya di Kota Jambi membutuhkan informasi akuntansi manajemen terutama informasi berupa informasi masa lalu seperti pelaporan informasi keuangan, analisis kemampuan menghasilkan laba, berapa biaya yang dikeluarkan dan informasi masa yang akan datang yaitu dalam penentuan harga jual batik.

\section{Perumusan Masalah}

a. Apakah ada pengaruh penggunaan informasi akuntansi manajemen, kepribadian wirausaha terhadap pengembangan kewirausahaan bidang ekonomi kreatif di Kota Jambi

b. Apakah ada pengaruh penggunaan informasi akuntansi manajemen terhadap pengembangan kewirausahaan bidang ekonomi kreatif di Kota Jambi

c. Apakah ada pengaruh kepribadian wirausaha terhadap pengembangan kewirausahaan bidang ekonomi kreatif di Kota Jambi

\section{Tujuan Penelitian}

a. Untuk mengetahui dan menganalisis apakah ada pengaruh penggunaan informasi akuntansi manajemen, kepribadian wirausaha terhadap pengembangan kewirausahaan bidang ekonomi kreatif di Kota Jambi

b. Untuk mengetahui dan menganalisis apakah ada pengaruh penggunaan informasi akuntansi manajemen terhadap pengembangan kewirausahaan bidang ekonomi kreatif di Kota Jambi

c. Untuk mengetahui dan menganalisis apakah ada pengaruh kepribadian wirausaha terhadap pengembangan kewirausahaan bidang ekonomi kreatif di Kota Jambi

\section{METODE PENELITIAN}

Penelitian ini menggunakan variabel independen penggunaan informasi akuntansi manajemen $\left(\mathrm{X}_{1}\right)$, kepribadian wirausaha $\left(\mathrm{X}_{2}\right)$ dan variabel dependen yaitu pengembangan kewirausahaan (Y) yang dapat dilihat dari kinerja yang dilakukan oleh pemilik UKM/UMKM. Jenis data yang digunakan adalah data primer yang diperoleh dari kuesioner yang disebarkan ke UKM/UMKM yang bergerak di bidang ekonomi kreatif khususnya para perajin batik di Kota Jambi. Populasi penelitian ini adalah para perajin batik yang ada di Kota Jambi. Pengambilan sampel dengan menggunakan purposive sampling dimana yang akan dijadikan sampel adalah para perajin batik yang ada di Kecamatan Danau Teluk dan Kecamatan Pelayangan. 
Tabel 1. Operasionalisasi Variabel

\begin{tabular}{|c|c|c|c|c|}
\hline $\begin{array}{c}\text { Variabel } \\
\text { Informasi } \\
\text { Akuntansi } \\
\text { Manajemen } \\
\left(\mathrm{X}_{1}\right)\end{array}$ & $\begin{array}{l}\quad \text { Konsep } \\
\text { informasi yang } \\
\text { dihasilkan oleh } \\
\text { akuntansi } \\
\text { manajemen } \\
\text { menekankan } \\
\text { hubungan antara } \\
\text { informasi } \\
\text { keuangan dengan } \\
\text { manajer yang } \\
\text { bertanggung } \\
\text { jawab terhadap } \\
\text { perencanaan dan } \\
\text { pelaksanaannya. } \\
\text { Untuk } \\
\text { mengimplementas } \\
\text { ikan fungsi } \\
\text { tersebut, maka } \\
\text { aktivitas dalam } \\
\text { perencanaan dan } \\
\text { pengendalian } \\
\text { memerlukan } \\
\text { berbagai bentuk } \\
\text { informasi dalam } \\
\text { bentuk laporan } \\
\text { keuangan dan } \\
\text { laporan } \\
\text { sejenisnya, } \\
\text { berupa laporan } \\
\text { rutin (terstuktur) } \\
\text { dan tidak rutin } \\
\text { (tidak terstruktur) } \\
\text { atau laporan } \\
\text { analitik. Laporan } \\
\text { rutin berisi } \\
\text { informasi } \\
\text { akuntansi untuk } \\
\text { manajemen yang } \\
\text { diterbitkan secara } \\
\text { akumulatif bulan, } \\
\text { triwulan, kwartal, }\end{array}$ & $\begin{array}{l}2 \text { Laporan Tidak } \\
\text { Rutin }\end{array}$ & 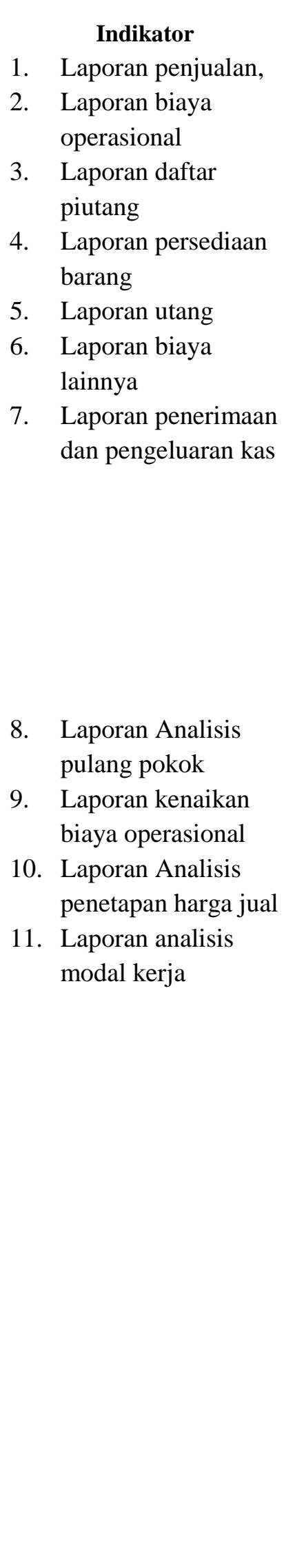 & $\begin{array}{c}\text { Pengukuran } \\
\text { Skala } \\
\text { Ordinal }\end{array}$ \\
\hline
\end{tabular}




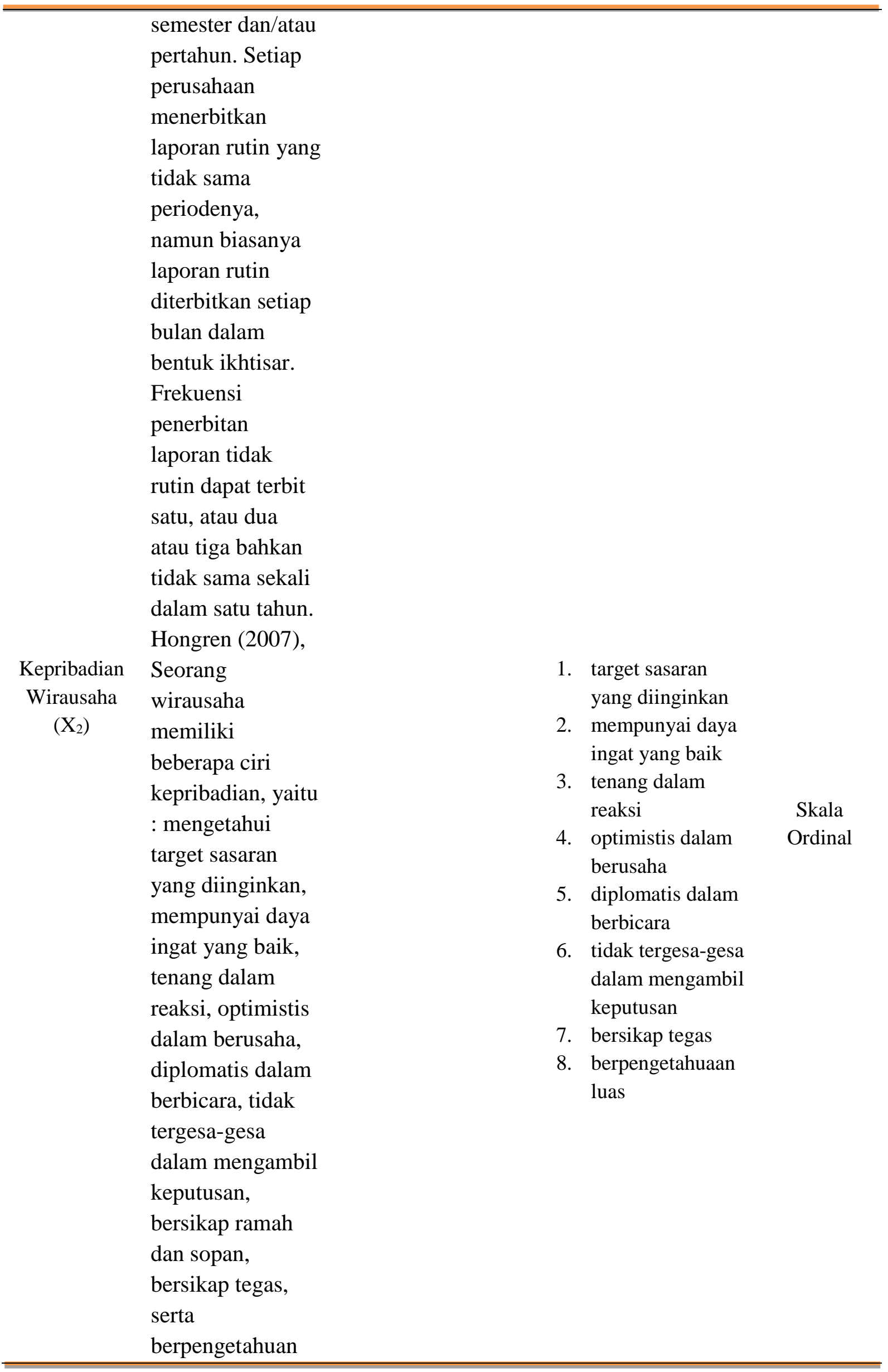




\begin{tabular}{cllll}
\hline & luas...” & & & \\
& Machfoedz & & & \\
Pengembang & (2004) & Ukuran & & \\
an & keberhasilan & 1. Perencanaan & Skala \\
kewirausaha & manajer/pemilik & 2. investigasi & Ordinal \\
an & usaha dalam & 3. pengkoordinasia & \\
$($ Y) & mencapai & n & \\
& tujuannya. & 4. evaluasi & \\
& Ritonga, (2008) & 5. pengawasan & \\
& & 6. pemilihan staff & \\
& & 7. negosiasi & \\
\hline
\end{tabular}

Instrumen yang valid dan reliabel dalam mengumpulkan data sangat diperlukan untuk mendapatkan hasil penelitian yang juga valid dan reliabel. Instrumen valid dapat mengungkapkan sesuatu yang menjadi sasaran pokok pengukuran (Hadi, 2000:11). Pengujian validitas instrumen dilakukan dengan menggunakan uji Pearson Product Moment Coefficient of Corelation. Instrumen akan dinyatakan valid jika memiliki tingkat signifikan dibawah 5\%, sedangkan Indikator untuk uji reliabilitas adalah Cronbach Alpha, apabila nilai Cronbach Alpha > 0.6 menunjukkan instrumen yang digunakan reliabel (Nunnally, 1969 dalam Ghozali, 2002).

Penelitian ini menggunakan alat analisis regresi berganda dengan terlebih dahulu mengkonversikan skala ordinal ke skala interval melalui metode interval berurutan (Method of successive interval). Asumsi klasik yang digunakan dalam penelitian ini adalah uji normalitas, asumsi Multikolinearitas, Heteroskedastisitas .

Berikut ini adalah persamaan yang digunakan dalam penelitian:

$$
Y=\alpha+\beta_{1} X_{1 i t}+\beta_{2} X_{2 i t}+\varepsilon
$$

Keterangan:

$Y \quad=$ pengembangan kewirausahaan

$\alpha \quad=$ Koefisien konstanta

$\beta \quad=$ koefisien variabel independen

$X_{\text {lit }} \quad=$ penggunaan informasi akuntansi manajemen

$X_{2 i t} \quad=$ Kepribadian wirausaha

$\varepsilon \quad=$ Error Term

\section{HASIL DAN PEMBAHASAN}

Penelitian ini menggunakan data primer yang diperoleh dengan menggunakan instrumen penelitian berupa kuesioner berisi pertanyaan yang telah dikirimkan kepada seluruh responden yaitu pemilik dan perajin batik di Kota Jambi. Setiap responden menjawab tiga puluh pertanyaan (30) pertanyaan terdiri atas sebelas (11) pertanyaan terkait dengan 
penggunaan sistim informasi akuntansi, sebelas (11) pertanyaan terkait dengan kepribadian wirausaha dan delapan (8) pertanyaan terkait dengan pengembangan kewirausahaan.

Berdasarkan kuesioner yang telah disebarkan dapat dilihat bahwa presentase jumlah responden dengan jenis kelamin laki-laki yaitu 30\% dengan jumlah 12 orang dan jumlah responden jenis kelamin perempuan $70 \%$ dengan jumlah 28 orang responden. Tingkat pendidikan responden lulusan SD 12 orang (30\%), SLTP 8 orang (20\%), SLTA 17 orang $(42,5 \%)$ dan sarjana 3 orang $(7,5 \%)$. Responden yang tingkat pendidikan SLTA merupakan responden terbanyak dengan persentase $42,5 \%$. Jika dilihat dari masa kerja responden masa kerja kurang 5 tahun 6 orang (15\%), masa kerja 5 sampai 10 tahun sebanyak 19 orang $(47,5 \%)$ dan masa kerja lebih dari 10 tahun sebanyak 15 orang $(37,5 \%)$. Responden yang berusia 20 sampai 30 tahun sebanyak 5 orang (12,5\%), 30 sampai 40 tahun sebanyak 12 orang $(30 \%)$, berusia 40 sampai 50 tahun sebanyak 14 orang $(35 \%)$ dan diatas 50 tahun sebanyak 8 orang $(22,5 \%)$.

Data yang diperoleh berupa data yang berskala ordinal. Oleh karena itu, sebelum masuk ke uji selanjutnya, data ordinal yang diperoleh dari hasil kuesioner harus diubah menjadi data interval dengan menggunakan Method of Successive Interval. Hal ini bertujuan untuk memenuhi syarat dalam analisis jalur dimana data harus berskala interval. Statistik deskriptif dalam penelitian ini digunakan untuk memberikan informasi mengenai variabel-variabel penelitian ini seperti penggunaan informasi akuntansi manajemen, kepribadian wirausaha dan pengembnagan kewirausahaan. Statistik deskriptif memberikan gambaran atau deskriptif suatu data yang dilihat dari minimum, maksimum, rata-rata (mean), deviasi standar dari masing-masing penelitian. Hasil analisis deskriptif dari variabel-variabel penelitian ini yang diolah dengan menggunakan SPSS 22 adalah sebagai berikut:

Uji normalitas pada model regresi digunakan untuk menguji apakah nilai residual yang dihasilkan dari regresi berdistribusi secara normal atau tidak. Model regresi yang baik adalah yang memiliki nilai residual yang berdistribusi secara normal. Beberapa metode uji normalitas yaitu dengan melihat penyebaran data pada sumber diagonal pada grafik Normal Probability Plot of Regression standarlized residual. Hasil pengujian di bawah ini, terlihat bahwa titiktitik menyebar di sekitar garis diagonal dan mengikuti arah diagonal atau grafik histrogramnya. Hal ini berarti bahwa nilai residual yang dihasilkan dari regresi berdistribusi secara normal atau memenuhi asumsi klasik.

Uji multikolinearitas bertujuan untuk menguji apakah dalam model regresi ditemukan adanya korelasi antar variabel bebas (independen). Jika ditemukan korelasi antar variabel independen, maka adanya masalah multikolinearitas. Model regresi yang baik seharusnya tidak menimbulkan masalah multikolinearitas (Ghozali, 2011). Metode pengujian yang paling sering digunakan dengan melihat nilai Tolerance dan Variance Inflation Factor (VIF) pada model regresi. Kriterianya yaitu jika nilai Tolerance variabel lebih besar dari 0,10 dan nilai VIF lebih kecil dari 10, maka tidak terjadi multikolinearitas.

Uji heteroskedastisitas bertujuan untuk menguji apakah model regresi terjadi ketidaksamaan varian dari residual satu pengamatan ke pengamatan lain. Menurut Ghozali (2011) bahwa jika varian data residual satu pengamatan ke pengamatan lain tetap, maka disebut homokedastisitas dan jika berbeda disebut heteroskedastisitas. Model regresi yang baik adalah yang homokedastisitas atau tidak terjadi heteroskedastisitas. Koefisien determinasi pada intinya menyatakan seberapa baik suatu model untuk menjelaskan variasi 
variabel dependen (Ghozali, 2011). Nilai $\mathrm{R}^{2}$ yang semakin tinggi menjelaskan bahwa semakin cocok variabel independen menjelaskan variabel dependen. Semakin kecil nilai $\mathrm{R}^{2}$ berarti semakin sedikit kemampuan variabel-variabel independen untuk menjelaskan variabel dependen.

Pengujian ini bertujuan untuk menguji pengaruh penggunaan informasi akuntansi manajemen dan kepribadian wirausaha terhadap pengembangan wirausaha secara simultan. Pengujian ini dilakukan pada tingkat signifikansi $(\alpha)$ sebesar $5 \%$ atau 0,05 .

\section{Hipotesis 1}

Berdasarkan hasil uji $\mathrm{f}$ terlihat bahwa nilai f hitung sebesar 1.556 dengan tingkat signifikansi 0,225. Menggunakan tingkat signifikansi 5\% atau 0,05 maka $\mathrm{H}_{1}$ ditolak. Hal ini dibuktikan dengan nilai signifikansi yang lebih besar dari 0,05. Ini berarti bahwa secara simultan penggunaan informasi akuntansi manajemen dan pengembangan kepribadian tidak berpengaruh terhadap pengembangan wirausaha. Penelitian ini tidak sejalan dengan penelitian sebelumnya Bayu Kartib (2007), Ki Marzuki (2009), Aditya Fitri Siregar (2009), Wiwi Idawati (2009), Devi (2014), yang mengatakan sistem informasi manajemen dan kepribadian wirausaha berpengaruh terhadap kinerja atau pengembangan usaha.

\section{Hipotesis 2}

Berdasarkan pengujian penggunaan informasi akuntansi manajemen terhadap kinerja manajerial menghasilkan nilai statistik t sebesar 1.589 dengan tingkat signifikansi p-value sebesar 0.121 . Oleh karena $p$-value lebih besar dari 0,05 maka $\mathrm{H}_{2}$ ditolak yang berarti bahwa penggunaan informasi akuntansi manajemen tidak berpengaruh signifikan terhadap pengembangan kewirausahaan. Penelitian ini tidak sejalan dengan penelitian sebelumnya Ki Marzuki (2009), Wiwi Idawati (2009), Devi (2014), yang mengatakan sistem informasi manajemen berpengaruh terhadap kinerja. Penelitian ini berbeda disebabkan ada beberapa penyebab antara lain bahwa UKM batik di Kota Jambi belum memanfaatkan sistem informasi akuntansi yang terlihat dari jawaban responden mereka jarang atau sangat jarang membuat laporan rutin maupun laporan tidak rutin

\section{Hipotesis 3}

Berdasarkan Pengujian variabel kepribadian wirausaha terhadap pengembangan kewirausahaan menghasilkan nilai statistik t sebesar -0.914 dengan tingkat signifikansi $p$ value sebesar 0.366 . Oleh karena nilai $p$-value lebih besar dari 0,05 maka $\mathrm{H}_{3}$ ditolak yang berarti bahwa kepribadian wirausaha tidak berpengaruh signifikan terhadap pengembangan wirausaha. Penelitian ini tidak sejalan dengan penelitian Bayu Kartib (2007), Aditya Fitri Siregar (2009) yang menyatakan bahwa kepribadian wirausaha berpengaruh terhadap pengembangan kewirausahaan. Hal ini disebabkan beberapa faktor antara lain karena UKM batik Kota Jambi kebanyakan adalah usaha turun temurun yang masih melakukan manajemen kekeluargaan sehingga kepribadian wirausaha dalam diri mereka bukan karena tekanan atasan ke bawahan tetapi adanya rasa tanggung jawab menjalankan usaha keluarga. Pengetahuan yang perajin peroleh tentang usaha batik pun kebanyakan adalah pengetahuan yang diperoleh secara otodidak.

$$
\mathrm{Y}=5.535+1.589 \mathrm{X}_{1}-0.914 \mathrm{X}_{2}
$$

Persamaan regresi berganda tersebut dapat diinterprestasikan sebagai berikut: 
1. Konstanta sebesar 5.535 memberikan arti bahwa apabila penggunaan informasi akuntansi manajemen $\left(\mathrm{X}_{1}\right)$, kepribadian wirausaha $\left(\mathrm{X}_{2}\right)$, diasumsikan $=0$, maka pengembangan wirausaha nilainya sebesar 5.535

2. Koefisien regresi variabel penggunaan informasi akuntansi manajemen $\left(b_{1}\right)$ sebesar 1.589 memberikan arti bahwa penggunaan informasi akuntansi manajemen satu-satuan maka akan terjadi kenaikan pengembangan wirausaha sebesar 1.589.

3. Koefisien regresi variabel kepribadian wirausaha $\left(b_{2}\right)$ sebesar -0.914 memberikan arti bahwa dengan penurunan kepribadian wirausaha satu-satuan maka akan terjadi kenaikan pengembangan wirausaha sebesar 0.914

\section{KESIMPULAN DAN SARAN}

\section{Kesimpulan}

1. Variabel penggunaan informasi akuntansi manajemen $\left(\mathrm{X}_{1}\right)$, kepribadian wirausaha $\left(\mathrm{X}_{2}\right)$, secara simultan tidak memiliki pengaruh terhadap pengembangan kewirausahaan (Y) bidang ekonomi kreatif Kota Jambi

2. Variabel penggunaan informasi akuntansi manajemen $\left(\mathrm{X}_{1}\right)$, kepribadian wirausaha $\left(\mathrm{X}_{2}\right)$, secara parsial tidak memiliki pengaruh terhadap pengembangan kewirausahaan (Y) bidang ekonomi kreatif Kota Jambi

\section{Saran}

1. Bagi perajin batik agar dapat memanfaatkan sistem informasi manajemen seperti membuat laporan- laporan seperti laporan rutin dan laporan tidak rutin

2. Bagi perajin batik agar memiliki kepribadian seperti memiliki pengetahuan yang banyak tentang seluk beluk usaha batik dan sikap optimis yang tinggi.

3. Bagi peneliti selanjutnya dapat melakukan penelitian pada bidang usaha kerajinan lainnya atau menambah populasi penelitian dengan mengambil seluruh kecamatan yang ada di Kota Jambi dan pengambilan sampel secara acak.

\section{DAFTAR PUSTAKA}

Anoraga. Pandji. 2007. Pengantar Bisnis. Pengelolaan Bisnis dalam Era Globalisasi. Jakarta. Rineka Cipta

Azhar Susanto. 2002. Sistim Informasi Manajemen Konsep dan Pengembangannya. Edisi 2. Bandung. Linggajaya

Andi, Kiagus. 2004. Pengaruh Informasi Akuntansi Manajemen Terhadap Kinerja Manajer Produksi: Survei pada Perusahaan Publik Manufaktur Makanan dan Minuman di Indonesia. Jurnal Akuntansi dan Keuangan, Vol. 9, No. 2.

Bayu, Kartib. 2007. Pengaruh Sikap Wirausaha Manajer dan Partisipasi Anggota Terhadap Implementasi Strategi Pemasaran Produk dan Implikasinya Terhadap Kinerja Usaha Koperasi. Majalah Ilmiah Unikom Vol.8, No. 2.

Hongren, Charles, T. 2007. Akuntansi Keuangan. Jilid Satu. Edisi Tujuh. Jakarta. Penerbit Erlangga 
Ki Marzuki. 2009. Pengaruh Pengendalian Intern, Sistem Informasi Manajemen dan Kapasitas SDM Terhadap Kinerja Manajerial (Studi Pada Lembaga Keuangan Mikro di Kota Banda Aceh). Universitas Abulyatama Aceh

Machfoedz, Mas'ud dan Mahmud Machfoudz. 2004. Kewirausahaan Suatu Pendekatan Kontemporer. Yogyakarta:UPP AMP YKPN

Mulyadi. 1997 Akuntansi Manajemen. Yogyakarta : Penerbit STIE YKPN.

Nely Marlina.2014. Apa itu UKM dan UMKM? Bagaimana Perkembangan di Indonesia. http://goukm.id

Ritonga, Panangaran.2008. Pengaruh Budaya Paternalistik dan Komitmen Organisasi Terhadap Hubungan Antara Partisipasi Anggaran dan Kinerja Manajerial pada PDAM Tirtanadi Propinsi Sumatera Utara. Tesis Universitas Sumatera Utara. Medan.

Rosmiati. 2012 . Analisis Program Bantuan Modal Kredit Usaha Penguatan Ekonomi Masyarakat (KUPEM) Oleh Pemerintah Kota Jambi Terhadap Pengembangan Usaha Mikro Kecil dan Menengah di Kota Jambi. Menkeu, Vol. 1, No. 3, 2012:239-244

Suryana. 2013. Kewirausahaan Kiat dan Proses Menuju Sukses. Penerbit Salemba Empat. Jakarta

Tambunan, Tulus (2002) "Peranan UKM bagi Perekonomian Indonesia dan Prospeknya "Usahawan -N0-07,Th XXXI-Juli, Hal 3-15. 